

\title{
Building Back Better: What Does it Imply for Jiri Technical School, Dolakha, Nepal ?
}

\author{
Amit Koirala \\ Research and Development Department \\ Training Institute for Technical Instruction (TITI) \\ Sanothimi, Bhaktapur, Nepal \\ Email for correspondence: ak@titi.org.np or amit_me63@yahoo.com
}

\begin{abstract}
A powerful earthquake of 7.8 magnitude struck on April 25, 2015 in Nepal. The impact was most severe where 8,790 casualties and 23,300 injured (National Planning Commission [NPC], 2015). Due to earthquake there was huge loss in education sector. In TVET sector Jiri Technical School, Dolakha, Nepal faced huge loss where almost all classroom including workshops, labs, hostel and cafeteria were damage. So, this study tries to portray the understanding perception of Jiri Technical School students on impact of earthquake on education and also educational resilience by using case study research design.
\end{abstract}

Keywords: Technical education, earthquake and educational resilience

\section{Setting the scene}

On Saturday, 25 April 2015 at 11:56 local time, a 7.8 magnitude earthquake as recorded by Nepal's National Seismological Centre (NSC), struck Barpak, district of Gorkha, about $76 \mathrm{~km}$ northwest of Kathmandu. Nepal had not faced a terrible natural shock of comparable magnitude for over 80 years.

The tragic earthquake was followed by more than 300 aftershocks greater than magnitude 4.0 (as of 7 June 2015). Four aftershocks were greater than magnitude 6.0, including one measuring 6.8 which struck 17 days after the first big one with the epicenter Sunkhani near Mount Everest (Government of Nepal, Ministry of Science, Technology and Environment, 2015). To date, there are over 8,790 casualties and
22,300 injuries. It is estimated that the lives of eight million people, almost one-third of the population of Nepal, have been impacted by these earthquakes. Thirty one districts have been affected, out of which 14 were declared 'crisis-hit' and another 17 neighboring districts were partially affected (National Planning Commission [NPC], 2015).

The destruction was widespread covering large number of residential and government buildings, heritage sites, schools and health posts, rural roads, bridges, water supply systems, and agricultural land (United Nations Office for the Coordination of Humanitarian Affairs [UNOCHA], 2015). Rural areas in the central and western regions were particularly devastated and further isolated due to 
road damage and obstructions. In the worst hit areas, entire settlements, including popular tourist destinations like Langtang, were swept away by landslides and avalanches triggered by the earthquakes (NPC, 2015). Hundreds of historical and cultural monuments at least a century old were either destroyed or extensively damaged. Over half a million houses were destroyed. Poorer rural areas have been more adversely affected than towns and cities due to their inferior quality of houses. More women and girls died than men and boys, partly because of gendered roles that disproportionately assign indoor chores to women (NPC, 2015).

According to NPC (2015) the net value of the total damages and losses to the education sector is estimated at NPR 31,317.9 million (US\$313.2 million) at pre-disaster prices. Of this, the damage to infrastructure and physical assets is estimated at NPR 28,063.8million (US\$ 280.6 million).

Likewise, in the TVET sector, the majority of the reported damage was faced by the Jiri Technical School in Dolakha (completely damaged). A total of 356 TVET classrooms were fully destroyed and another 184 were partially damaged, together with significant damage to equipment and other assets (NPC, 2015). During my field visit to Jiri Technical School (JTS) I found that the school was completely damage and the classes were running in temporary building. Student's hostels where also temporary build including cafeteria. After observing JTS, number of questions rose in my brain. How JTS students perceive impact of earthquake on education? What educational resilience or building back better means to them? So this paper tries to understand the perception of JTS students on impact of earthquake on education and also educational resilience or building back better to them.

\section{Case Study Design Rationale}

The case study as Yin (2003) and Flyvbjerg (2006) believe falls under constructivist paradigm. Researching on the understanding the perception of the effects of earthquake in public technical school fits here as it focuses to answer process questions (Yin, 2003). A case study is a specific instance that is frequently designed to study a more general principle and practices (Flyvbjerg, 2006); it is also known as the study of an instance in action (Yin, 2003). Case study in true essence explores and as a research method investigates contemporary real life phenomenon through detailed contextual analysis of limited number of events or conditions, and their relationships (Zainal, 2007). Case studies are considered useful in research as they enable researchers to examine data at micro level. As an alternative to quantitative or qualitative research, case study can be a practical solution when a big sample population is difficult to obtain (Zainal, 2007).

The qualitative case study facilitates to explore the phenomenon within the context using variety of resources. It helps to see the issues through variety of lenses which allows multiple facts of the phenomenon to be reveled and understood (Baxter $\&$ Jack, 2008). So, here researchers try to explore the phenomena within the context using the variety of resources. As the researchers we have chosen social constructivist worldview and compose observation and open ended interview (Creswell, 2009).

\section{Sources of Evidences, Tool and Respondents}

A pre-study by the researchers to the study unit helped to define the informant for the researcher. The three sources of evidences (Yin, 2003) were predetermined in the first visit; interview, observation and documents of Jiri Technical School (JTS) were the major information sources to get to the research question. The participants were JTS students who were interviewed guided by the themes. The field notes during the visit stood as the second information and the details (in document) provided were also used in the study.

\section{Proximity: Basis of my study sites and samples}

The idea of qualitative research is to select research 
participants, documents or visual materials purposefully that will best answer the research questions (Patton, 2002). Thus, in qualitative research, qualitative inquiry focuses on small samples that are selected purposefully. In consultation with my professors and technical education and vocational training expert, I have purposefully selected Jiri Technical School (JTS) at Jiri, Dolakha, Nepal. JTS enjoys the rural life style and school had been destroyed due to the earthquake that hit in April 2015 so I have selected JTS site and participant purposefully for my study because Creswell (2011) says that in qualitative research, researcher select or identify the sites or participants purposefully which help researcher to understand research problem in a best way.

\section{Purposive selection of diverse research participants}

For my study, I have selected six key participants for interviews, three students from JTS, two teachers from JTS and one administration staff of JTS. I was present there (JTS) for my follow up study of instructional skill training. I participated in their teaching learning class room, their workshop practical classroom and their field visit in Jiri, Dolakha, Nepal and I had observed my participants daily life activities and social interaction in community as well as response of society to them.

\section{Understanding Immediate Impact of the earthquake in JTS}

I was present in JTS in the month of May, 2016 for my follow up study of instructional skill (IS1) training. It was approximately 5 PM evening that I reached Jiri. As I move towards JTS from the local bus stop I observed the main gate of JTS was broken. When I went inside to school building from the broken main gate I observed a different school environment. Debris everywhere and some debris still left to manage. Old infrastructure almost damage and those left infrastructure where cracked. I saw temporary classroom and administration building. In 2012 I had made my visit to JTS and I was inspired by its learning environment but now (May, 2016) due to devastating earthquake I found almost all infrastructure damage. I observed students studying in temporary classroom and residing in temporary hostel. Looking all this cosmology I want to understand how they perceive their education in aftermath of earthquake. One of my participants Mukesh (Pseudonym, student, 20 years, male, construction trade) said:

\section{I fainted as my school hostel collapsed. When I woke up I found myself outside of the school hostel. Even now earthquake tremors remind me of that terrible day.}

The earthquake had particular impact on JTS students. Still they fear from that terrible earthquake. When digging more questions my participant said me when somebody moves him or pushes his desk unknowingly than he feels that again earthquake struck JTS. From this narrative inquiry of Mukesh I made meaning was that still earthquake has created negative psychological effect on JTS students.

\section{Effects on teaching and learning}

The effects of the earthquake on infrastructure and physical assets are relatively easy to observe and it is more difficult to estimate effect of the earthquake on teaching and learning activity. The earthquake and its aftershocks led to the complete closure of schools for more than a month (26 April-30 May) in JTS. The standard school opening days per year is 220, with 190 days for teaching learning and the rest for examinations, extracurricular activities, and other non-teaching functions (NPC, 2015). In the consultations with the administration staff I found that the number of days lost would eventually be covered through cuts in winter vacation and annual festivals. One of my participant Ruja (Pseudonym, student, 19 years, female, health trade) states that

due to earthquake I lost my learning habit and I am not confident as I was before. When I have to carry my practical work I feel less motivated and its because of earthquake. Our practical room and community room was 
all destroyed and we have to do in playground.

From the narrative inquiry of Ruja I made meaning was that due to terrible earthquake that struck at JTS effects on teaching and learning environment. Teaching and learning environment plays a vital role in all round development of student (Koirala \& Chaudhary, 2015). From the devastating earthquake I made meaning was that students lost their motivation and confidence in their study. Their learning habits have been disrupted. Raju furthermore says:

I am fear that I may have forgotten what I have learned and may have difficulty in passing my board exam.

From the narrative inquiry of my participant it made me clear that due to earthquake students of JTS had lost their motivation in respect to their studies and this lost motivation can create negative effect towards their study. Sharma (2012) also states that motivation towards learning is vital thing for learner to enhance learning activity.

\section{Effects on teachers and education personnel}

The total casualty to teachers is reported at 49 (including two in higher education) in Nepal (NPC, 2015). While there is no reported casualty to the teaching personnel in JTS. Teachers from the JTS have lost their homes and family members, and household burdens to female teachers have increased. In my field visits, teachers stated that they would be able to resume teaching learning activities as it was before the earthquake. However, they raised concerns regarding availability of housing, need for advance payment, and additional training to facilitate students and psycho-social counseling. One of my participants Ram (Pseudonym, Teacher, 36 years, male, health trade) states that:

I am living in a single room which is temporarily build with my family and my condition is miserable. It is very difficult to perform effective teaching and learning in this situation but also I am managing somehow. School should take necessary initiation for teacher because here teacher had also lost their home and family members.

From the narrative inquiry of my participant I made meaning was that not only students but also teachers were affected from earthquake and are in miserable condition. Teachers are the role model for students and they learn different skill from teacher (Sharma, 2012). So, school and concern stakeholders should take significant steps to uplift these teachers who were victimized due to terrible earthquake.

\section{Effects on service delivery and governance mechanisms}

During consultations with principle of JTS he said: there has been major damage to the administrative building, classrooms and workshop affecting their day-to-day operations. There have been delays in conducting the examinations by JTS, and they have already postponed or rescheduled their examinations. This is unlikely to affect the schedules planned for next year. One of my participants Manoj (Pseudonym, teacher, 30 years, male, construction trade) states that:

In JTS due to earthquake nothing are in order and sometimes it takes even more than a day to find an instrument. Examinations are approaching near and we have pressure to complete our course on time. Teaching in temporary classroom is also not effective. It produce echo and create disturbance to next classroom.

From the narrative inquiry of my participant I made meaning was that due to earthquake it is difficult in teaching learning activity. I also observed that due to earthquake everything was out of order including labs, workshops and classrooms. Sharma (2012) also states that to achieve all round development of students, teachers, students, school and parents should take directly and indirectly involvement in teaching learning process but here JTS I found less involvement as stated by Sharma (2012). 


\section{Building back better: what does it imply ?}

In education building back better notion should encompass not only physical infrastructure improvement which could be made, but also the addressing of others pre-existing access and quality gaps (Kirk, 2008). Even from a physical reconstruction perspective, building back better has to imply more than just rebuilding the school in the same place, same design and with same facilities. It should imply a careful chosen school site, earthquake resistance design and students friendly with adequate classroom, labs, workshops, recreational space, latrine, water and be a space for teacher to gather and share their experience and resources and also made to feel part of a professional community (Bird, 2009). In remote areas where communities rely on teachers from outside, a better built school should include simple teacher accommodation.

At the same time during my field visit in JTS and interviewing my participants I made meaning was that building back better has many more meaning and implication including improvement in access to education, and especially for girls. One of my female participants Ruja said:

Girls should be provided more facility than boys because in this crucial period of earthquake boys are safer and they can adjust easily everywhere but in case of girls it is difficult to adjust at any place.

During my field visit in JTS I observe that girls facing difficulty in common toilet system. Likewise quality improvement such as better teaching and learning materials, teacher with better pedagogical skills supported by principal or head teacher is necessary. Better monitoring, feedback and accountability system are also required to promote quality teaching and administration. Holistically building back better also implies enhanced community engagement in education and real consultation and participation from students, parents and community member in educational decision making.

\section{Conclusion}

Building back better in JTS is strong and significant for qualitative change. Enhancing disaster resilience is not only about building back better from a structural perspective. It requires interventions in non-structural aspects of the education system such as the curriculum and textbooks to ensure that teachers and students internalize safety issues and can act in times of need. This also requires strengthened disaster preparedness and response at the school and community level through school-based disaster risk management and community based disaster risk management, training and planning.

\section{References}

Baxter, P., \& Jack, S. (2008). Qualitative case study methodology: Study design and implementation for novice researchers. Ontario, Canada: McMaster University.

Bird, L. (2009). Promoting resilience: developing capacity within education systems affected by conflict. Paris: UNESCO. Retrieved from www.unesdoc.unesco.org/images/0019/001913 /191302e.pdf

Creswell, J. W. (2009). Qualitative inquiry and research design. New Delhi: Sage.

Creswell, J.W. (2011). Research design: Qualitative, quantitative and mixed methods approaches (3rd ed.). India: Sage Publication.

Flyvbjerg, B. (April, 2006). Five misunderstanding about case-study research. Qualitative Inquiry, 12, pp. 219-245. doi: 10.1.1.144.851.

Government of Nepal, Ministry of Science, Technology and Environment. (2015). Nepal earthquake 2015 rapid environmental assessment. Kathmandu: Author.

Kirk, J. (2008). Building back better: Post earthquake response and educational challenge in pakistan. Paris: UNESCO. Retrieved from:www.unesco.org 
/iiep/PDF/pubs/2008/Pakistan.pdf

Koirala, A \& Chaudhary, P. (2015). Foundation of education and learning. Lalitpur: Orchid books pvt ltd.

National Planning Commission. (2015). Nepal earthquake 2015: post disaster needs assessment. Kathmandu: Author.

Patton, M.Q. (2002). Qualitative evaluation and research methods (3rd ed.). Thousand: Sage.

Sharma, C. (2012). Curriculum planning and practices. Kathmandu: MK publishers.

UNOCHA. (2015). Nepal earthquake flash appeal revision, april-september 2015. Kathmandu: Author. Retrieved from https://www.humanitari anresponse.info/en/operations/nepal/document /nepal-flash-appeal-response-nepal-earthquake april-september-2015.

Yin, R. K. (2003). Case study research design (3rded.). New Delhi, Sage.

Zainal, Z. (2007). Case study as research method. Malaysia: University Technology. 